\title{
Chemical Characteristics and Viability of Starter Cultures of Freeze-Dried Sweet Potato Extract-Supplemented Synbiotic Yogurt
}

\author{
Agustina Intan Niken Tari ${ }^{1, *}$, Catur Budi Handayani ${ }^{1}$, Sri Hartati ${ }^{1}$, Damat Damat $^{2}$, \\ and Karina Stankeviča ${ }^{3}$ \\ ${ }^{1}$ Department of Agricultural Product Technology, Faculty of Agriculture, \\ University of Veteran Bangun Nusantara Sukoharjo, Jl. Letjend Sujono Humardani no. 1, \\ Sukoharjo 57521, Central Java, Indonesia \\ ${ }^{2}$ Department of Food Science and Technology, Faculty of Agriculture and Animal Science, \\ University of Muhammadiyah Malang, Jl Raya Tlogomas No. 246, Malang 65144, \\ East Java, Indonesia \\ ${ }^{3}$ Department of Environmental Science, University of Latvia, Raina Blvd.19, \\ Riga LV-1050, Latvia
}

\begin{abstract}
The research aimed to determine the sucrose concentration as a cryoprotectant to obtain the chemical properties and the viability of Lactic Acid Bacteria (LAB) and Lactobasillus plantarum in the synbiotic yogurt. It adopted a one-factor Completely Randomized Design (CRD) by including sucrose in concentrations from $0 \%, 2.5 \%, 5 \%$ to $7.5 \%$, three replications. The results showed various sucrose concentrations significantly affected the yields of the purple sweet potato extractsupplemented synbiotic yogurt, reduction-sugar level, the total of LAB, and the total of L. plantarum before and after the freeze-drying process, no significant impact on the moisture content and total quantity of LAB. The best treatment of the synbiotic yogurt was induced through the addition of sucrose with a concentration of $5 \%$ as a cryoprotectant. The treatment signified the following characteristics: $14.797 \%$ of yields, $7.51 \%$ of water content, $14.59 \%$ of reduction-sugar level, $1.98 \times 10^{9} \mathrm{CFU}$ $\mathrm{mL}^{-1}$ of total LAB before the freeze-drying and $9.28 \times 10^{8} \mathrm{CFU} \mathrm{mL}^{-1}$ after

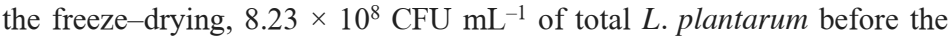
freeze-drying and $6.81 \times 10^{8} \mathrm{CFU} \mathrm{mL}^{-1}$ after the freeze-drying.
\end{abstract}

Key words: Healthy consumption, fermented drink, functional food, free radical, sucrose as cryoprotectant.

\section{Introduction}

Together with the increasing public awareness on the importance of healthy foods, the consumer demands related to food qualifications have begun to shift. Consumers currently look for foods that contain not only a good nutritional composition with attractive appearance and taste but also certain physiological impacts for the body, such as its benefits

\footnotetext{
*Corresponding author: intanniken@gmail.com
} 
to maintain the balance of intestine microbiota and immune system. The healthy consumption pattern can be achieved through the addition of synbiotic yogurt. The types of symbiotic yogurt include local probiotic-based yogurt and purple sweet potato extract-supplemented yogurt.

Tari et al. [1] Reported that purple sweet potato extract-supplemented yogurt made from commercial cultures and indigenous probiotics, such as Streptococcus thermophilus FNCC 0040, Lactobacillus bulgaricus FNCC 0041, and Lactobacillus plantarum Dad 13 by the ratio 1: 1: 0.5 had nowbeen available completed with the physical properties $(\mathrm{pH}=3.78$, viscosity $=5.1987 \mathrm{cP}$, chromatic color $=18.559)$ and chemical properties (titrated acid content $=1.2733 \%$, moisture content $=85.2664 \%$, ash content $=0.8041 \%$, reduction sugar level $=3.3278 \%$, dissolved protein content $=1.4782 \%$, fat content $=0.08 \%$, and anthocyanin level $=8.5315 \%$ ).

Tari et al. [2] also shared that indigenous probiotics, such as L. plantarum Dad 13 supplemented to the purple sweet potato extract yogurt, could act as a diarrhea-lowering agent in experimental animals. The discovery was indicated by the decreasing water content of the experimental animals' feces from $63.32 \%$ to $62.73 \%$, in addition to the decreasing water content of the experimental animals' cecum from $83.31 \%$ to $35.13 \%$. The indigenous probiotics are also able to reduce free radical components as indicated by the decreasing blood MDA level of the experimental animals from $4.23 \mathrm{mmol} \mathrm{mL}^{-1}$ to $1.52 \mathrm{mmol} \mathrm{mL}^{-1}$ and the decreasing liver MDA level at from $5.60 \mathrm{mmol} \mathrm{mL}^{-1}$ to $2.96 \mathrm{mmol}$ $\mathrm{mL}^{-1}$ at the end of the study.

According to [3], fermented milk products must be stored at a temperature of less than $10{ }^{\circ} \mathrm{C}$ to avoid negative environmental impacts. The storage at low temperature functions to inhibit the fermentation process thus will maintain a high number of microbes. This treatment, however, will result in high storage and distribution costs deal with the challenges, freeze-dried synbiotic yogurt could offer the solution.

Cruz [4] explained that the freeze-drying process could reduce the number of bacteria by $1 \log$ cycle, as the process allows the microbial death (sublethal). Therefore, the addition of protective substances (cryoprotectant) before the freeze-drying process is required to minimize the damage.

The common use of coating material (cryoprotectant) derives from encapsulants, such as gum, carbohydrates, and protein to coat the core materials (bacteria) with specific purposes, such as to cover up the bad taste and odor, protect against the environmental influences, increase the stability, and prevent evaporation. This cryoprotectant material can be either carbohydrates or protein.

According to [5] the use of protein as a cryoprotectant can maintain the bacterial resistance, while the use of carbohydrates can both improve microcapsule texture and maintain the bacterial resistance. Bhat [6] stated that sucrose could function as a protective material for bacteria. It is safe for consumption and able to increase sweetness. The addition of sucrose as a cryoprotectant function to protect the structure and proteins in microbial cells [7].

However, there have yet been available any relevant studies that proved the function of sucrose as a cryoprotectant agent in lactate-fermented drinks such as indigenous probiotic yogurt (local) produced from sweet potato supplementation through a freeze-drying process to the viability of Lactic Acid Bacteria (LAB) and L. plantarum Dad 13, in addition to its characteristics. The notion underlies this research background.

This research aims to signify the effect of sucrose concentration as cryoprotectant on the yields, water content, reduction-sugar level, total LAB, and total L. plantarum Dad 13 of the freeze-dried lactate-fermented drinks. 


\section{Materials and methods}

\subsection{Materials}

The research used a number of materials, which consisted of LAB cultures from the Universitas Gadjah Mada (UGM) Yogyakarta, Indonesia FNCC (Food and Nutrition Culture Collection). The bacterial cultures were identified in upright shapes, including S. thermophilus FNCC 0040, L. bulgaricus FNCC 0041, and L. plantarum Dad 13 as probiotic indigenous LAB cultures which were collected from UGM Researchers Association. The MRS (de Mann Rogosa Sharpe) Agar/Broth (Oxoid) media was utilized for the LAB culture maintenance. Meanwhile, the LPS media was utilized as the selective media for the L. plantarum Dad 13 growth. Other supporting chemical substances were $70 \%$ of alcohol, methylated spirit, and distilled water that were obtained from the Biological-Chemistry and Microbiology Laboratory, Faculty of Agriculture, University of Veteran Bangun Nusantara Sukoharjo, Central Java, Indonesia. The research utilized several instruments, including glasswares (test tubes, beaker cups, Erlenmeyer flasks, and petri dish), autoclaves (All America), an incubator, an oven (binder), and a laminar airflow (LAF).

\subsection{Research procedure}

The research procedures ranged from the preparation of bacterial culture stocks, starter culture, purple sweet potato extract, and probiotic yogurt through supplementation of purple sweet potato extract, and freeze-drying process.

\subsubsection{Preparation of bacterial culture stocks}

The commercial bacteria (S. thermophilus FNCC 0040 and L. bulgaricus FNCC 0041) and L. plantarum Dad 13 as indigenous probiotic LAB cultures in the form of agar slants were taken one ose and grown in a $10 \mathrm{~mL}$ sterile liquid MRS. The cultures were then etched in a sterile agar slant and incubated at $37{ }^{\circ} \mathrm{C}$ during $24 \mathrm{~h}$ to $48 \mathrm{~h}$. The stocks of bacterial cultures in the agar slants were stored in a refrigerator at $2{ }^{\circ} \mathrm{C}$ to $3{ }^{\circ} \mathrm{C}$ and regenerated once every $2 \mathrm{wk}$.

\subsubsection{Preparation of purple sweet potato extract}

The procedure of purple sweet potato extraction referred to the preliminary research conducted by [8]. The procedure was begun by dice-cutting the sweet potatoes in a $5 \mathrm{~cm} \times 5 \mathrm{~cm}$ cube size and extracting the cuts in a juicer. The product was then left to stand for $24 \mathrm{~h}$ at a $4{ }^{\circ} \mathrm{C}$ temperature, so the purple sweet potato starch would settle, while the filtrate would remain. The filtrate of the purple sweet potato extract would be taken to produce theyogurt.

\subsubsection{Preparation of starter cultures}

This stage included the preparation of $5 \mathrm{~mL}$ sterile liquid MRS media in three tubes. Each tube was then inoculated with the upright-shaped bacterial cultures, including S. thermophilus FNCC 0040, L. bulgaricus FNCC 0041, and L. plantarum Dad 13. All of the isolated cultures were incubated at a $37{ }^{\circ} \mathrm{C}$ temperature for $24 \mathrm{~h}$. To produce the starter cultures, every $0.1 \mathrm{~mL}$ of the cultures were then inoculated into $5 \mathrm{~mL}$ sterile skimmed milk 
and incubated at a $40{ }^{\circ} \mathrm{C}$ temperature for $7 \mathrm{~h}$ to $8 \mathrm{~h}$ or at a $37{ }^{\circ} \mathrm{C}$ temperature for $24 \mathrm{~h}$. From this phase, the total production of LAB and L. plantarum Dad 13 as the starter cultures reached by $109 \mathrm{CFU} \mathrm{mL}^{-1}$.

\subsubsection{Preparation of purple sweet potato extract-supplemented yogurt}

Fresh milk, skimmed milk $\left(5 \% \mathrm{w} \mathrm{v}^{-1}\right)$, and purple sweet potato extract $\left(10 \% \mathrm{v} \mathrm{v}^{-1}\right)$ were pasteurized at the temperature ranged from $72{ }^{\circ} \mathrm{C}$ to $80{ }^{\circ} \mathrm{C}$ for $30 \mathrm{~min}$ and cooled at the temperature ranged from $40{ }^{\circ} \mathrm{C}$ to $45{ }^{\circ} \mathrm{C}$. The product was aseptically inoculated with $5 \%\left(\mathrm{v} \mathrm{v}^{-1}\right)$ S. thermophilus, L. bulgaricus, and L. plantarum Dad 13 probiotic bacteria by the ratio $1: 1: 0.5$ at the temperature ranging from $40{ }^{\circ} \mathrm{C}$ to $45{ }^{\circ} \mathrm{C}$. The product was then shaken until it reached a homogeneous state and incubated at a $40{ }^{\circ} \mathrm{C}$ temperature for $8 \mathrm{~h}$ or at a $30{ }^{\circ} \mathrm{C}$ temperature for $20 \mathrm{~h}$ to produce purple sweet potato extract-supplemented yogurt.

\subsubsection{Freeze-drying process for lactate-fermented drink}

The yogurt produced from the supplementation of purple sweet potato extract and probiotics (L. plantarum Dad 13) was added with sucrose (consecutively based on the treatment) and skimmed milk $\left(10 \% \mathrm{v} \mathrm{v}^{-1}\right)$. The yogurt was then aseptically stirred until it reached a homogeneous state. The mixture was put into freeze-dryer glass tubes and frozen at a $-20^{\circ} \mathrm{C}$ temperature for $12 \mathrm{~h}$. The product was dried in a freeze-dryer for $10 \mathrm{~h}$.

\subsubsection{Research design}

The research used a Completely Randomized Design (CRD) through a single treatment by including sucrose (S) as a cryoprotectant with the variations of concentration percentage, including $\mathrm{S}_{1}=0 \%, \mathrm{~S}_{2}=2.5 \%, \mathrm{~S}_{3}=5 \%$, and $\mathrm{S}_{4}=7.5 \%$. The study was conducted by three times of replications, thus 12 experimental units were produced. The observation parameters consisted of the viability of L. plantarum Dad 13 before and after the freeze-drying treatment, total viability of LAB before and after the freeze-drying treatment, moisture content, solubility, and reduction-sugar level. The data were analyzed using the RAL One-Way ANOVA. The treatment would proceed to the DMRT test, if the result showed a real significance [9].

\subsubsection{Observation parameter}

The experiment tested the fermented products and dried products in order to find out: The yields of freeze-dried purple sweet potato extract synbiotic yogurt, the result of moisture content test through a thermogravimetric method [10], the result of reduction-sugar level test through the Nelson Somogyi method [11], the total LAB before and after the freeze-drying process, and the viability of L. plantarum Dad 13. All of the tests utilized the Bacteriological Analytical Manual (BAM) method (2002).

\section{Result and discussions}

\subsection{Yields of purple sweet potato extract-supplemented synbiotic yogurt}

The yields of purple sweet potato extract-supplemented synbiotic yogurt (PSPE-SSY) was the final product following the freeze-drying process. The content of yields (Y) was 
generated by the formula (1):

$$
\mathrm{Y}(\text { Yield })=\frac{\text { PSPE-SSY after freeze drying }}{\text { PSPE-SSY after freeze drying }} \times 100 \%
$$

The addition of $10 \%$ skimmed milk as a cryoprotectant combined with various concentrations of sucrose gave a significant effect $(p<0.05)$ to the yields of the freeze-dried yogurt. The statistical test result was explained in Figure 1.

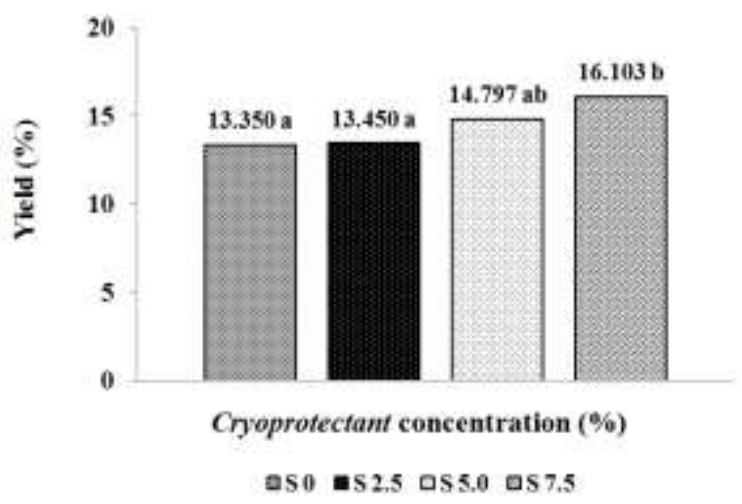

Fig. 1. Impact of various sucrose concentrations on yields of freeze-dried purple sweet potato extract-supplemented synbiotic yogurt

Figure 1 signifies that a higher sucrose concentration resulted in a higher quantity of the freeze-dried synbiotic yogurt yields. The condition was due to the combination of skimmed milk and sucrose to increase the volume and total of material solids. This research was relevant to [11] who concluded that the increase of yields was affected by the large amount of cryoprotectant that resulted in a higher total of material solids. A high total of material solid correlates with a large quantity of yields.

\subsection{Moisture content}

The moisture content of the final products became an important parameter in making instant products. The combination of $10 \%$ skimmed milk and various concentrations of sucrose as a cryoprotectant indicated no impact on the moisture content of the freeze-dried purple sweet potato extract-supplemented synbiotic yogurt $(p>0.05)$ as shown in Figure 2 . Such a condition was possible due to the small interval of sucrose concentration used as a cryoprotectant, thus offered less impact on the moisture content of the product. The use of sucrose was cryoprotective as a drying medium, as it can form porous structures to facilitate the release of the product moisture during the freeze-drying process and become the medium at the rehydration process [12]. 


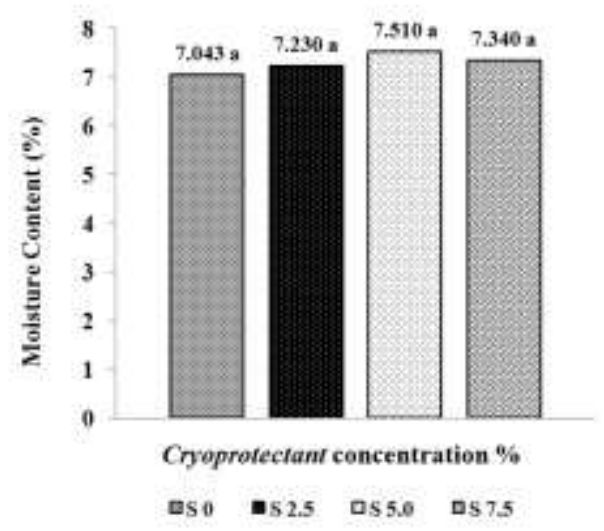

Fig. 2. Impact of various sucrose concentrations on moisture content of freeze-dried purple sweet potato extract-supplemented synbiotic yogurt.

\subsection{Reduction-sugar level}

A reduction-sugar is a group of monosaccharides and disaccharides that have free-reducing groups, such as glucose, fructose, lactose, galactose, and maltose [13]. Figure 3 showed that the concentration of the cryoprotectant made from combination of $10 \%$ skimmed milk and various sucrose concentrations had a significantly different impact $(p<0.05)$ on the reduction-sugar of the freeze-dried purple sweet potato extract-supplemented synbiotic yogurt.

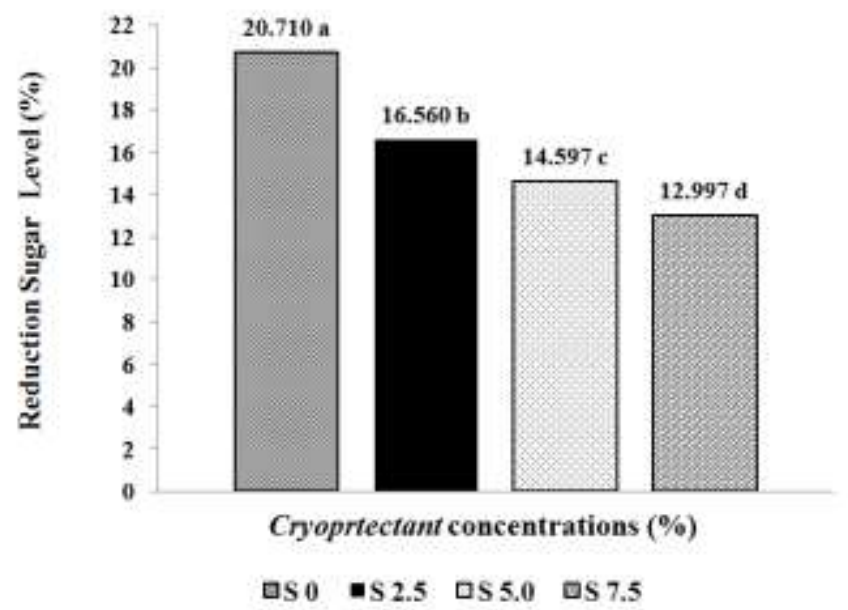

Fig. 3. Impact of various sucrose concentrations on reduction-sugar level of freeze dried purple sweet potato extract-supplemented synbiotic yogurt

The decreasing reduction-sugar level was considered due to its use as the energy source for the bacterial cell growth and propagation, in addition to the formation of bacterial metabolites during the freeze-drying process. Such a condition was concluded from the total average of LAB that ranged from $12.93 \times 10^{8} \mathrm{CFU} \mathrm{mL}^{-1}$ to $39.77 \times 10^{8} \mathrm{CFU} \mathrm{mL}^{-1}$ or

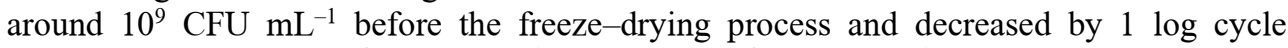

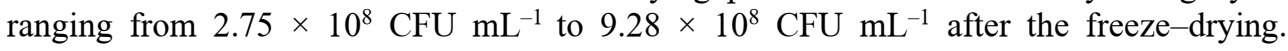
The total average of $L$. plantarum before the freeze-drying process ranged from 


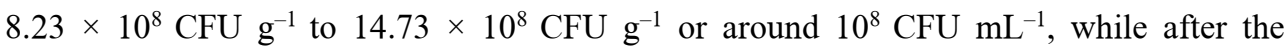
freeze-drying process, the total average of L. plantarum ranged from $1.74 \times 10^{8} \mathrm{CFU} \mathrm{mL}^{-1}$ to $6.81 \times 10^{8} \mathrm{CFU} \mathrm{mL} \mathrm{m}^{-1}$ following the addition of cryoprotectant. The data confirmed the findings shared by [14] that lactic acid bacteria utilized sugar as the energy source for its growth and produced lactic acid during the fermentation process.

\subsection{The total of Lactic Acid Bacteria (LAB)}

The measurement of the total of LAB is an important parameter, as it closely relates to the amount of skimmed milk and sucrose as the cryoprotectant. Li et al. [15] stated that a good protector in the freeze-drying process ought to be cryoprotective, easy to dry, able to form a good matrix to maintain cell stability, and easily rehydrated. Sucrose is one of the cryoprotectants that meet with these criteria. The effect of sucrose concentration as cryoprotectant on the total LAB was explained in Figure 4.

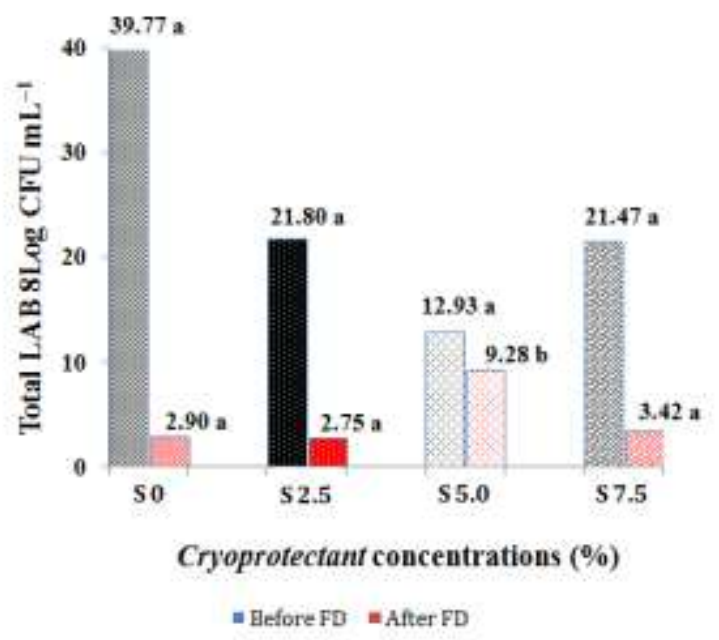

Remarks:Numbers with the same alphabetical notations signify real indifferent results in DMRT test with an $\alpha$-value $=0.05$

Fig. 4. The total of LAB in synbiotic yogurt before and after freeze-drying process

Figure 4 showed that the total of LAB before the freeze-drying process ranged from

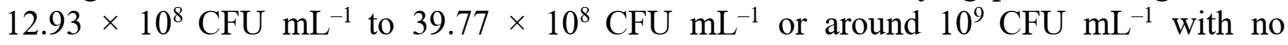
significant difference $(p>0.05)$ at various sucrose concentrations. After the freeze-drying process, the total of LAB decreased by $1 \log$ cycle that varied from $2.75 \times 10^{8} \mathrm{CFU} \mathrm{mL}^{-1}$ to

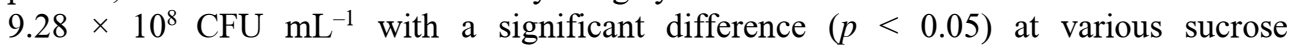
concentrations.

The total of $\mathrm{LAB}$ at the $5 \%$ sucrose concentration as the cryoprotectant showed a significantly different number among other treatments. The reduction in the total of LAB at the $5 \%$ sucrose concentration before and after the freeze-drying process showed the smallest number which was less than 1 log cycle. It was suspected that sucrose as the cryoprotectant could protect the structure and function of microbial cell proteins [7]. Additionally, sucrose could also function to strengthen the cell resistance to the freezing condition. The mechanism of cryoprotectant function in the reaction of cell preservation is marked by, i) the decreasing freezing point of the cryoprotectant medium, ii) the protective reaction of cell membranes, and iii) the suppressing rate of a high concentration effect [15]. 
An over-high concentration of sucrose $(7.5 \%)$ could lead to the osmotic imbalance inside and outside the bacterial cells. The condition would potentially spur bacterial lysis and cause bacterial death. Figure 4 signifies a lower total of LAB at the $7.5 \%$ sucrose concentration compared to the $5 \%$ sucrose concentration.

\subsection{The total of L. plantarum Dad 13}

The enumeration of L. plantarum Dad 13 in the freeze-dried purple sweet potato extract-supplemented synbiotic yogurt utilized the LPSM (L. plantarum Selective Medium). It is a simple medium which is sensitive to L. plantarum and other potentially probiotic Lactobacillus species $[15,16]$. The medium contains a $4 \mu \mathrm{g} \mathrm{mL} \mathrm{m}^{-1}$ concentration of ciprofloxacin, as an antibiotic that functions to inhibit most of the infectious bacteria, including the endogenous acid lactic bacteria that grow in MRS agar, however, has no adverse effect on the recovery of $L$. plantarum. The effect of sucrose concentration as the cryoprotectant on the total of L. plantarum is explained in Figure 5.

Figure 5 showed that the total average of L. plantarum before the freeze-drying process ranged from $8.23 \times 10^{8} \mathrm{CFU} \mathrm{g}^{-1}$ to $14.73 \times 10^{8} \mathrm{CFU} \mathrm{g}^{-1}$ or around $10^{8} \mathrm{CFU} \mathrm{mL} \mathrm{g}{ }^{-1}$ with a significant difference $(p<0.05)$ among various sucrose concentrations. After the freeze-drying process, the total average of $L$. plantarum following the addition of cryoprotectant at various sucrose concentrations $(0 \%, 2.5 \%, 5 \%$, and $7.5 \%)$ ranged from

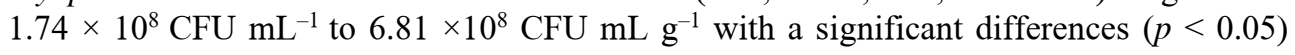
among various sucrose concentrations. At the control treatment $\left(\mathrm{S}_{1}=0 \%\right)$, the total average of L. plantarum decreased by 1 log cycle following the freeze-drying phase. The total average of $L$. plantarum after the sucrose treatment at various concentrations from $2.5 \%$, $5 \%$, to $7.5 \%$ also decreased, however not by $1 \log$ cycle.

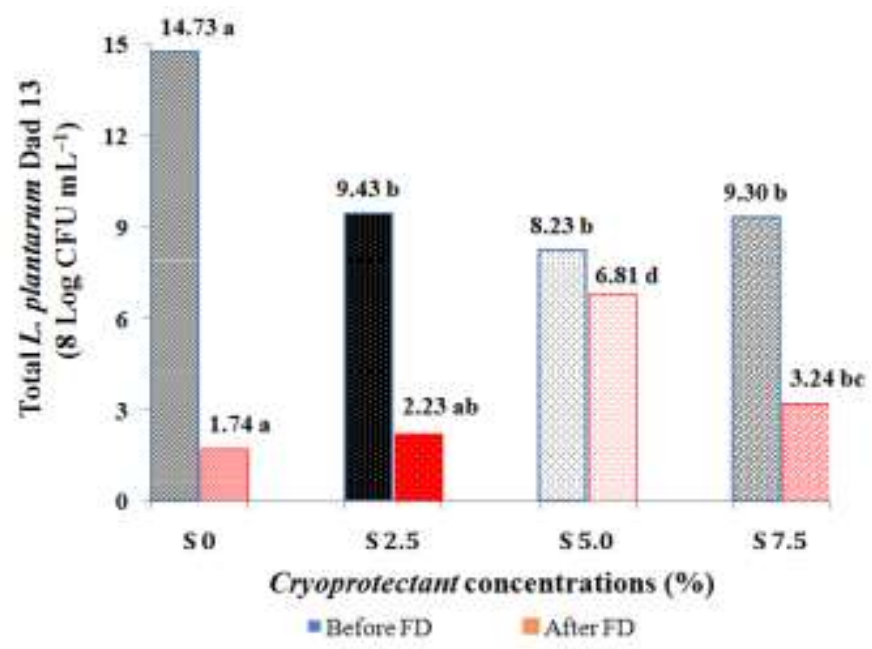

Remark: Numbers with the same alphabetical notations signify real indifferent results in DMRT test with an $\alpha$-value $=0.05$.

Fig. 5. The total of L. plantarum of synbiotic yogurt before and after freeze-drying process

Figure 5 indicated that the decreasing cell viability was probably due to the freeze-drying process. The freezing process caused the cell to lose its stability, thus it became easily damaged during the drying process. The osmotic shock was suspected as the main factor of the bacterial cell damage during the drying process, as signified by the membrane damage and displacement of hydrogen bonds that affected the hydrophilic 
macromolecule properties of the bacterial cells [17].

Another factor that affected the cell viability was the selection of cryoprotectant materials. According to [18], the use of two types of encapsulants from protein and carbohydrate matrices can produce a higher efficiency compared to the use of one type of encapsulant. It happens as the encapsulants can interact in forming granules, thus they can better overlay the encapsulated components.

The skimmed milk which contains lactose also provides good protection against the freeze-drying effects. The components of lactose in the form of glucose and galactose include simple sugars with a low molecular weight that results in easy entry intobacterial cells and protect the two sides of the cell membranes during the freeze-drying process. The presence of sucrose as a cryoprotectant could protect the structures and functions of microbial cell proteins [7], thus sucrose could improve cell resistance in freezingconditions.

In addition to the external factors, internal factors also affect viability. L. plantarum bacteria are gram-positive bacteria. According to [19], the g-positive bacteria have a cell composition that consists of $90 \%$ peptidoglycan, lipids (1\% to $4 \%$ ), teichoic acid, and other components. The composition caused the gram-positive bacteria to be more resistant to physical and enzymatic treatments, such as the freeze-drying process than the gram-negative bacteria.

\section{Conclusions}

The various sucrose concentrations significantly affected the yields of the freeze-dried purple sweet potato extract-supplemented synbiotic yogurt, reduction-sugar level, the total of LAB, and the total of L. plantarum before and after the freeze-drying process. However, there were indicated no significant effects on the moisture content and total quantity of LAB. The best treatment was shown in the freeze-dried purple sweet potato extract-supplemented synbiotic yogurt with a $5 \%$ of sucrose concentration as the cryoprotectant. The treatment using a $5 \%$ of sucrose concentration resulted in the following characteristics: A $14.797 \%$ of yields, a $7.51 \%$ of water content, a $14.59 \%$ of reduction-sugar level, a $1.98 \times 10^{9} \mathrm{CFU} \mathrm{mL}^{-1}$ of total $\mathrm{LAB}$ before the freeze-drying and a $9.28 \times 10^{8} \mathrm{CFU} \mathrm{mL} \mathrm{mL}^{-1}$ after the freeze-drying, a $8.23 \times 10^{8} \mathrm{CFU} \mathrm{mL}^{-1}$ of total L. plantarum before the freeze-drying and a $6.81 \times 10^{8} \mathrm{CFU} \mathrm{mL}^{-1}$ after the freeze-drying.

The researchers acknowledge the Directorate of Research and Public Submission of the Ministry of Research, Technologies, and Higher Education Affairs due to the 2018 National Strategic Research Grants. No. SP DIPA-042.06.1.401516/2018. December 052017.

\section{References}

1. A.I.N. Tari, C.B. Handayani, A.M.W. Mulyono. Bakteri probiotik terhadap mutu yogurt ekstrak ubi jalar ungudan pemanfaatannya sebagai pencegah diare dan imunomodulator [Probiotic bacteria on the quality of yogurt of purple sweet potato extract and its use as a prevention of diarrhea and immunomodulators]. Laporan Penelitian Hibah Bersaing. Universitas Veteran Bangun Nusantara Sukoharjo (2013). p.1-95. [in Bahasa Indonesia]. http://lppm.univetbantara.ac.id/data/materi/Laporan\%20PHB-I-\%20Fix.pdf

2. A.I.N Tari, C.B. Handayani, Sudarmi. Bakteri probiotik terhadap mutu yogurt ekstrak ubi jalar ungu dan pemanfaatannya sebagai pencegah diare dan imunomodulator [Probiotic bacteria on the quality of yogurt of purple sweet potato extract and its use as a prevention of diarrhea and immunomodulators]. Laporan Kemajuan Penelitian Hibah Bersaing. Universitas Veteran Bangun Nusantara 
Sukoharjo (2014). p. 1-34. [in Bahasa Indonesia].

http://ppm.univetbantara.ac.id/data/materi/Laporan\%20Kemajuan\%20PHB\%20ta hun\%20ke-2\%20Agustina\%20Intan\%20Niken\%20Tari.pdf

3. M.H.B. De Almeida, S.S. Zoellner, A.G. Da Cruz, M.R.L. Moura, L.M.J. De Carvalho, M.C.J. Freitas, et al. Int. J. Dairy Technol. 61: 178-182(2008). https://doi.org/10.1111/j.1471-0307.2008.00390.x

4. A.G. Cruz, E.H.M. Walter, R.S. Cadena, J.A.F. Faria, H.M.A. Bolini, H.P. Pinheiro, et al. Food Res. Int. 43,5:1444-1448(2010).

http://dx.doi.org/10.1016/j.foodres.2010.04.028

5. R. Heni, B.S.L. Jeni, N. Nurhidayat, C. Nurwitri. Anim. Prod. 10,3: 179-187(2008). http://repository.ipb.ac.id/handle/123456789/9429

6. A.R. Bhat, V.U. Irorere, T. Bartlett, D. Hill, G. Kedia, M.R. Morris, et al. AMB Expr. 3:1-9(2013). https://dx.doi.org/10.1186\%2F2191-0855-3-36

7. C.A. Morgan, N. Herman, P.A White, G. Vesey. J. Microbiol. Methods. 66,2: 183-193(2006). https://doi.org/10.1016/j.mimet.2006.02.017

8. A.I.N. Tari, C.B. Handayani, A.K. Sariri. Jurnal Teknologi Hasil Pertanian UNS. 1:1-7(2012). [in Bahasa Indonesia]. https://jurnal.uns.ac.id/ilmupangan/article/download/13530/11276

9. J. Sarwono, H.N. Salim. Prosedur-prosedur populer statistik untuk analisis data riset skripsi. [Popular statistical procedures for thesis research data analysis]. Gaya Media. Yogyakarta (2017). [in Bahasa Indonesia]. https://www.semanticscholar.org/paper/Prosedur-prosedur-Populer-Statistikuntuk-Analisis-Salim/ea2d356588baa0ecbd1365dd5f12e464eceb96ea

10. H.N. Al-Mentafji. AOAC. Official Methods of Analysis, 18th ed. AOAC International, Maryland (2005). p. 28.

https://www.researchgate.net/publication/292783651_AOAC_2005

11. S.S. Endang, Prasetyastuti. Jurnal Farmasi Kedokteran. 3,1:353-362(2010). [in Bahasa Indonesia]. https://docplayer.info/30784494-Pengaruh-pemberianjuice-lidah-buaya-aloe-vera-l-terhadap-kadar-lipid-peroksida-mda-pada-tikusputih-jantan-hiperlipidemia.html

12. P. Bordat, A. Lerbret, J.P. Demaret, F. Affouard, M. Descamps. EPL. 65 (2004). https://iopscience.iop.org/article/10.1209/epl/i2003-10052-0/pdf

13. V. Mougios. Exercise Biochemistry, $2^{\text {nd }}$ Ed. USA: Canada (2019). p. 1-472. https://books.google.co.id/books?id=udCMDwAAQBAJ\&printsec=frontcover\&dq $=$ V. + Mougios.+ Exercise + Biochemistry,$+2 n d+E d .+(2019) \& h l=e n \& s a=X \& v e d=2 a$ hUKEwjyj5OC8ebqAhUzmuYKHfhdD3cQ6AEwAXoECAUQAg\#v=onepage\&q $\& \mathrm{f}=$ false

14. A.S. Carvalho, J. Silva, P. Ho, P.H.P. Teixeira, F.X. Malcata, P. Gibb. Journal of INRA, EPD Science. 83,3:203-210(2003). https://doi.org/10.1051/lait:2003010

15. P. Li, Q. Gu, X. Wu. Protein Expr. Purif. 126:115-121(2016). https://doi.org/10.1016/j.pep.2016.06.007

16. V. Coeuret, M. GueGuen, J.P. Vermoux. J. Dairy Res. 71,4:451-460(2004). https://doi.org/10.1017/S0022029904000469

17. P. Kaushik, K. Dowling, C.J. Barrow, B. Adhikari. J. Funct. Foods. 19: 868-881(2015).https://doi.org/10.1016/j.jff.2014.06.029

18. A. Munin, F. Edwards-Lévy. Pharmaceutics. 3,4:793-829(2011). https://doi.org/10.3390/pharmaceutics3040793

19. S. Brown, J.P.S. Maria, S. Walker. Annu. Rev. Microbiol. 67:313-336(2013). https://doi.org/10.1146/annurev-micro-092412-155620 